\title{
Photodynamic Therapy with Pyoktanin Blue and Diode Laser for Elimination of Enterococcus faecalis
}

\author{
YOSHIKO MASUDA ${ }^{1,2}$, HIROSHI SAKAGAMI ${ }^{2}$, MASASHI HORIIKE ${ }^{1}$, HIROSHI KADOKURA ${ }^{1}$, \\ TAKAHIDE YAMASAKI ${ }^{1}$, PERRY R. KLOKKEVOLD ${ }^{3}$, HENRY H. TAKEI ${ }^{4}$ and SATOSHI YOKOSE ${ }^{1}$ \\ ${ }^{1}$ Division of Endodontics and Operative Dentistry, \\ Department of Restorative and Biomaterials Sciences, School of Dentistry, Meikai University and \\ ${ }^{2}$ Meikai University Research Institute of Odontology (M-RIO), Saitama, Japan; \\ ${ }^{3}$ Section of Postgraduate Periodontics and Implant Surgery, \\ School of Dentistry, University California, Los Angeles, CA, U.S.A.; \\ ${ }^{4}$ Section of Periodontics, School of Dentistry, University California, Los Angeles, CA, U.S.A.
}

\begin{abstract}
Background/Aim: Enterococcus faecalis is responsible for most cases of endodontic treatment failure. Despite various conventional disinfection methods, root canals are not completely free of microorganisms. Photodynamic therapy (PDT) is a new antimicrobial strategy that involves the use of a non-toxic photosensitizer (PS) and a light source. The aim of this study was to evaluate the antimicrobial effect of PDT using diode laser and pyoktanin blue $(P B)$ and confirm the nontoxicity of $P B$ as a PS. Materials and Methods: Laser irradiation with an output power of $3 \mathrm{~W}$ was performed with $P B$ as the PS to a bacterial solution containing E. faecalis. Then, the number of colony-forming units was counted. PB cytotoxicity was also assessed by the MTT assay. Results: E. faecalis counts were reduced after laser irradiation, laser irradiation with $P B$, or the combination thereof compared to the control, nonirradiation or water. The $50 \%$ cytotoxic concentration value for adult human dermal fibroblasts incubated with $P B$ for 1 min was $108 \mu \mathrm{g} / \mathrm{ml}$. Conclusion: Diode laser irradiation in combination with $P B$ as the PS is efficacious for the elimination of E. faecalis without toxic effects to human dermal fibroblasts. This strategy might be useful for root canal irrigants.
\end{abstract}

This article is freely accessible online.

Correspondence to: Yoshiko Murakami Masuda, DDS, Ph.D., Division of Endodontics and Operative Dentistry, Department of Restorative and Biomaterials Sciences, School of Dentistry, Meikai University, 1-1 Keyakidai, Sakado, Saitama 350-0283, Japan. Tel: +81 492792787, Fax: +81 492855171, e-mail: yoshik@dent.meikai.ac.jp

Key Words: Photodynamic therapy, pyoktanin blue, diode laser, root canal irrigants.
A high prevalence of Enterococcus faecalis is frequently observed in filled root canals associated with persistent apical periodontitis (1). Enterococci are Gram-positive cocci that can resist intracanal procedures and systemic antibiotics because of their morphological and genetic characteristics, even in ecologic conditions of stress (2). Therefore, E. faecalis is responsible for most cases of endodontic treatment failure (3). The complex anatomy of the root canal system (i.e., isthmuses, accessory canals, and dentinal tubules) enables the survival of bacteria after conventional cleaning (4). E. faecalis is capable of surviving in adequate nutritional conditions and can stay viable as a single microorganism (5). It can also penetrate into the dentinal tubules and form biofilms (6). Bacteria can penetrate into the dentinal tubules up to a depth of $1,250 \mu \mathrm{m}$ (7). Despite the availability of various conventional mechanical root canal cleaning methods and chemical irrigants, root canals are not completely free of microorganisms (4). The most frequently used irrigant, sodium hypochlorite, can only penetrate into the dentinal tubules up to a depth of $130 \mu \mathrm{m}$ (8). Therefore, more effective irrigant delivery and agitation systems are needed. Lasers have been proposed as an effective approach to cleaning and disinfecting. Vatkar et al. reported that lasers proved to be a valuable adjunct in the elimination of bacteria and could help reduce the incidence of postendodontic treatment failures (9). Various types of lasers have been investigated in an attempt to develop improved treatment methods (10). Recently, high-power lasers have been introduced for endodontic treatment (11). A study showed that an 810-nm diode laser obstructed the dentinal tubules and decreased Escherichia coli and E. faecalis bacterial counts (12).

Photodynamic therapy (PDT) is an adjunct method for the inactivation of bacteria (8). This antimicrobial strategy involves the use of a non-toxic photosensitizer (PS) and a light source (13). The PS reacts with molecular oxygen to 
produce highly reactive oxygen species, which injure and kill microorganisms $(8,14)$. For endodontic treatment, PDT with a diode laser $(810 \mathrm{~nm})$ and indocyanine green was shown to reduce bacteria in root canals (15-17).

Pyoktanin blue (PB) was used to stain a cyst during cystic brain tumor resection $(18,19)$.

In this study, we used a new 808-nm diode laser (OPELASER Filio; Yoshida Trade Dental Distribution Co., Ltd., Tokyo, Japan) with PB as the PS for PDT. The aim of this in vitro study was to evaluate the antimicrobial effect of PDT using the new diode laser 6uFilio and PB and confirm the nontoxicity of PB as a PS. The hypothesis was that PDT with $\mathrm{PB}$ would be efficacious for the elimination of $E$. faecalis without toxicity to human dermal fibroblasts.

\section{Materials and Methods}

Bacterial inoculation. E. faecalis standard strain (American Type Culture Collection BAA-2128 ${ }^{\mathrm{TM}}$ ) was cultured in $5 \mathrm{ml}$ brain heart infusion (BHI) broth (33 g/l; Sigma-Aldrich, St. Louis, MO, USA) and incubated at $37^{\circ} \mathrm{C}$ for $24 \mathrm{~h}$. The turbidity of the prepared media was adjusted to $0.2 \mathrm{McF}$ arland standard using a filter colorimeter. Then, $40 \mu \mathrm{l}$ cultured medium containing approximately $2 \times 10^{8}$ E. faecalis and $200 \mu 11 \%$ pyoktanin blue solution (PB; Wako Pure Chemical Industries, Ltd., Osaka, Japan) were added to a $1.5-\mathrm{ml}$ microtube (Watson Co., Ltd., Tokyo, Japan). As a control, $200 \mu \mathrm{l}$ sterilized distilled water was added instead of PB to the $1.5-\mathrm{ml}$ microtube containing E. faecalis.

Laser irradiation. A diode laser (OPELASER Filio; Yoshida Trade Dental Distribution Co., Ltd., Tokyo, Japan) was used. This laser emits light at a wavelength of $808 \mathrm{~nm}$ and has a flexible fiber delivery system $(\Phi=0.2 \mathrm{~mm})$. Laser irradiation was performed with an output power of $3 \mathrm{~W}$ with continuous waves at a distance of $6 \mathrm{~mm}$ from the bottom of the 1.5-ml microtube for 10, 20, 40, 50, and $60 \mathrm{sec}$. Controls were performed without laser irradiation and with laser irradiation for $60 \mathrm{sec}$ without PB. Figure 1 shows the experimental setup including the fiber tip of the diode laser and $1.5-\mathrm{ml}$ microtube containing the PB solution.

Microbiological procedures. Bacterial counts were determined after laser irradiation. First, $5 \mu \mathrm{l}$ bacterial sample was diluted with $1 \mathrm{ml}$ sterilized distilled water. Then, $10 \mu$ diluted bacterial solution was diluted with $1 \mathrm{ml}$ sterilized distilled water. Finally, $40 \mu \mathrm{l}$ bacterial solution was spread onto BHI agar plates (52 $\mathrm{g} / \mathrm{l}$ distilled water) and incubated at $37^{\circ} \mathrm{C}$ for $24 \mathrm{~h}$. The number of colony-forming units (CFUs) was then counted.

Cytotoxicity assay of PB. Adult human dermal fibroblasts (6 PDL) (HDFa; Gibco, Invitrogen, Grand Island, NY, USA) were plated in 96-well plates $\left(2.42 \times 10^{3}\right.$ cells/well, $0.1 \mathrm{ml} /$ well $)$ containing alphaminimum essential medium (Gibco, Invitrogen) with $10 \%$ heatinactivated fetal calf serum and incubated for $15 \mathrm{~min}$ to allow cell attachment. After $96 \mathrm{~h}$, the medium was replaced with $0.1 \mathrm{ml}$ fresh medium containing different concentrations of PB. Cells were further incubated for $1 \mathrm{~min}$. The medium was removed and cells were washed twice with fresh culture medium and then further incubated in fresh culture medium (Dulbecco's modified Eagle's

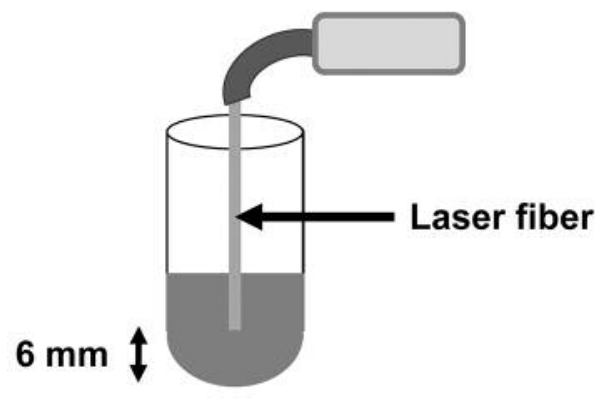

Figure 1. Schematic of the experimental setup including the fiber tip of the diode laser. Laser irradiation was performed at a distance of $6 \mathrm{~mm}$ from the bottom of the 1.5-ml microtube, which contained the pyoktanin blue solution.

medium $+10 \% \mathrm{FBS}$ ) for $48 \mathrm{~h}$ to determine the viable cell number by the 3-(4,5-dimethylthiazol-2-yl)-2,5-diphenyltetrazolium bromide (MTT) assay (20). Because 1\% dimethyl sulfoxide (DMSO) reduced the viability to $86 \%$ of the control, cytotoxicity derived from DMSO was subtracted from all data points. The relative viable cell number was determined by reading the absorbance of the cell lysate at $562 \mathrm{~nm}$ using a microplate reader (Infinite F50R; TECAN, Kanagawa, Japan). Control cells were treated with the same amounts of DMSO and cell damage induced by DMSO was subtracted from that induced by $\mathrm{PB}$. The concentration of PB that reduced the viable cell number by $50 \%$ $\left(\mathrm{CC}_{50}\right)$ was determined from the dose-response curve. The mean $\mathrm{CC}_{50}$ value was calculated from triplicate assays.

Statistical analysis. Comparisons between groups were statistically analyzed using the Mann-Whitney $U$-test. The percentage of reduction in colony count (\%RCC) was calculated using the following equation (15):

CFUs (before treatment)-CFUs (after treatment)

CFUs (before treatment)

$\times 100=\%$ RCC.

\section{Results}

Figure 2 shows E. faecalis colonies on BHI agar plates. Greater reductions in E. faecalis colony numbers were observed with longer laser irradiation time compared with the control (without laser and PB). At $60 \mathrm{sec}$, few colonies were detected on the plate (Figure 2). Furthermore, reductions in $E$. faecalis counts were observed after laser irradiation, $\mathrm{PB}$, or the combination thereof compared with the control (without laser and PB) (Figure 3).

Greater reductions were observed in the PB without laser group compared with the laser irradiation for 10 and $20 \mathrm{sec}$ group. Moreover, the reduction in E. faecalis count in the PB with laser irradiation at $40 \mathrm{sec}$ group was greater than that in the PB without laser irradiation group. At $50 \mathrm{sec}$ after laser irradiation with $\mathrm{PB}, \mathrm{RCC}$ was about $99 \%$ compared 


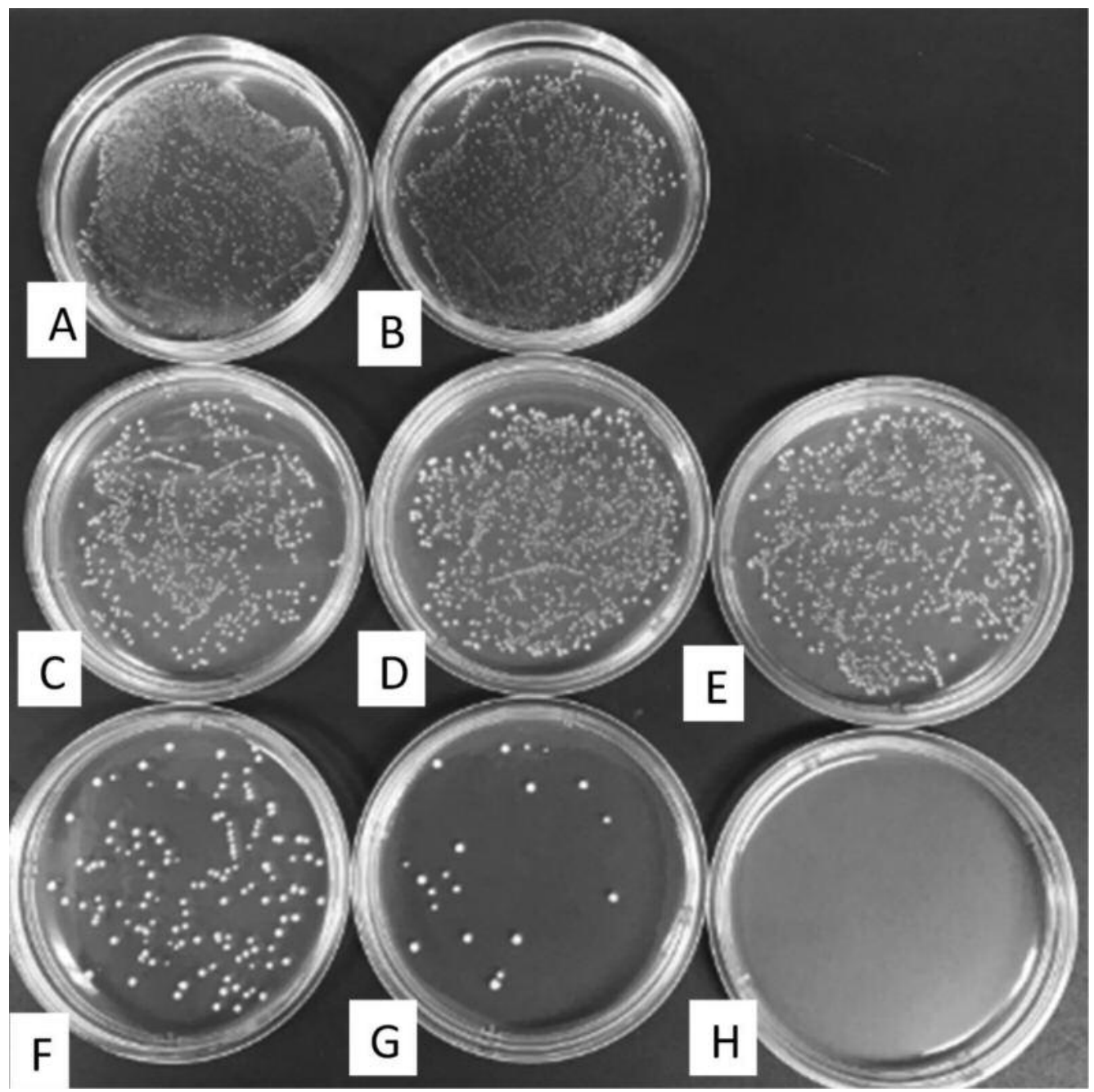

Figure 2. E. faecalis colonies on brain heart infusion agar plates. (A) Control without laser irradiation and pyoktanin blue (PB); (B) laser irradiation without $P B ;(C)$ PB without laser irradiation; $(D) P B$ with laser irradiation for 10 sec; $(E)$ PB with laser irradiation for 20 sec; $(F)$ PB with laser irradiation for $40 \mathrm{sec} ;(G) P B$ with laser irradiation for $50 \mathrm{sec} ;(H) P B$ with laser irradiation for 60 sec.

with the baseline value. At $60 \mathrm{sec}$ after laser irradiation with $\mathrm{PB}, \mathrm{RCC}$ was about $100 \%$ compared with the baseline value (Table I). Without PB, at $60 \mathrm{sec}$ after laser irradiation $\mathrm{RCC}$ was $48.45 \%$. Statistically significant differences were observed for all group comparisons (Mann-Whitney $U$-test; Table II).

Figure 4 shows the results of the cytotoxicity assay. HDFa cells were incubated with a range of $\mathrm{PB}$ concentrations and cytotoxicity was analyzed using the MTT assay after $1 \mathrm{~min}$ of incubation (Figure 4). Viable cell number was affected by both the PB incubation time and concentration. A shorter incubation time resulted in higher viable cell counts. Each value represents mean+S.D. $(n=6)$ The $\mathrm{CC}_{50}$ values of pyoktanin blue was $108 \mu \mathrm{g} / \mathrm{ml}$.

\section{Discussion}

Elimination of E. faecalis in the root canal has been explored by many investigators, and different irrigation techniques and devices have been developed to enhance the efficacy and distribution of irrigants (21). Lasers have been proposed as an alternative to conventional cleaning and disinfection approaches (22). PDT involves the interaction between light and a PS (a chemical compound that can be excited by light of a particular wavelength) in the presence of oxygen. The PS accumulates in the target cells (including bacterial and tumor cells) and then light of a specific wavelength is applied to the target cells. This causes oxidative damage to the target cells by inducing the production of reactive oxygen species (23). 


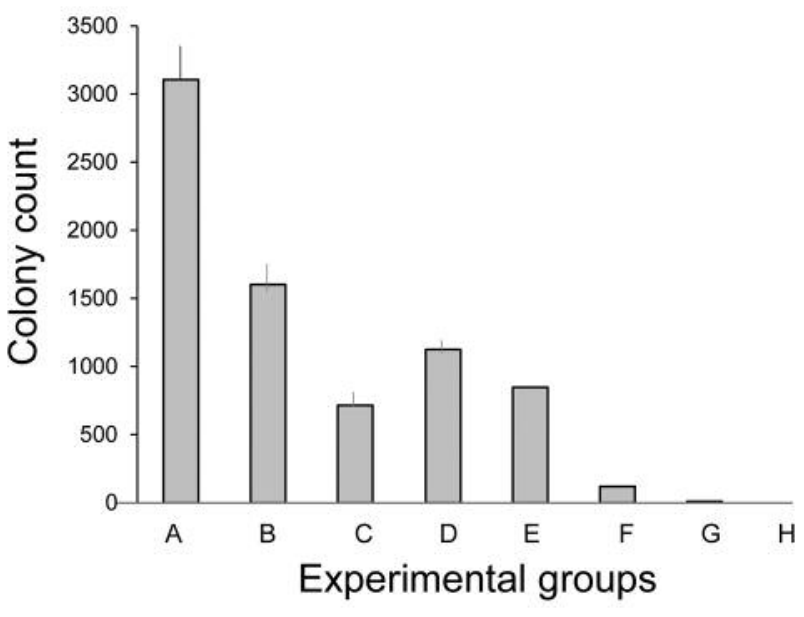

Figure 3. E. faecalis counts (colony-forming units). (A) Control without laser irradiation and pyoktanin blue $(P B) ;(B)$ laser irradiation without $P B ;(C) P B$ without laser irradiation; (D) $0.83 \%$ PB with laser irradiation for $10 \mathrm{sec}$; (E) $P B$ with laser irradiation for $20 \mathrm{sec}$; $(F) P B$ with laser irradiation for $40 \mathrm{sec}$; $(G) P B$ with laser irradiation for $50 \mathrm{sec} ;(H) P B$ with laser irradiation for $60 \mathrm{sec}$.

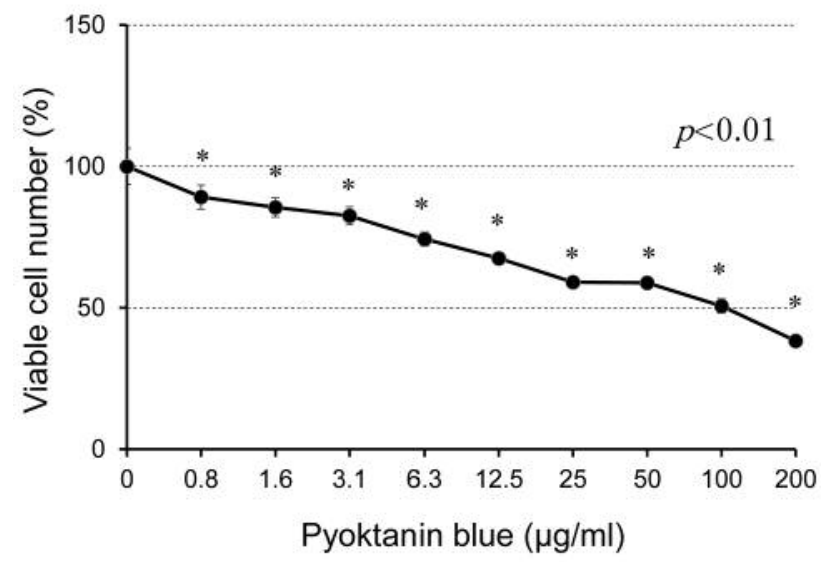

Figure 4. Cytotoxic activity of pyoktanin blue (PB). Confluent HDFa cells (6 PDL) $\left(2.42 \times 10^{3} / \mathrm{cm}^{2}\right)$ were inoculated into the 96-microwell plate and incubated for 3 days. Cells were exposed for 1 min to the indicated concentrations of pyoktanin blue. After washing twice with culture medium, cells were further incubated for $48 \mathrm{~h}$ with fresh culture medium to determine the viable cell number by the MTT method. Data represent the mean \pm standard deviation $(n=6) . * p<0.01 \quad C C_{50}$ of pyoktanin blue was $108 \mu \mathrm{g} / \mathrm{ml}$.

Siddiqui et al. reported in their systematic literature review that PDT effectively reduced $E$. faecalis counts in infected root canals compared with traditional endodontic instrumentation/irrigation treatment protocols (3). However, controversial results have also been reported. Nagayoshi $e t$
Table I. Enterococcus faecalis colony-forming units.

\begin{tabular}{lcccccc}
\hline & & & & \multicolumn{3}{c}{$\% \mathrm{RCC}$} \\
\cline { 5 - 7 } & & & & \multicolumn{3}{c}{ Before treatment } \\
\hline $\mathrm{A}$ & $(-)$ & $(-)$ & $3107 \pm 735$ & 0 & & \\
$\mathrm{~B}$ & $(-)$ & $60 \mathrm{~s}$ & $1601 \pm 123$ & 48.45 & 0 & \\
$\mathrm{C}$ & $(+)$ & $(-)$ & $715 \pm 110$ & 77 & & \\
$\mathrm{D}$ & $(+)$ & $10 \mathrm{~s}$ & $1125 \pm 70$ & 63.8 & 29.77 & $(-) 57.37$ \\
$\mathrm{E}$ & $(+)$ & $20 \mathrm{~s}$ & $846 \pm 14$ & 72.76 & 47.15 & $(-) 18.42$ \\
$\mathrm{~F}$ & $(+)$ & $40 \mathrm{~s}$ & $120 \pm 4$ & 96.14 & 92.51 & 83.21 \\
$\mathrm{G}$ & $(+)$ & $50 \mathrm{~s}$ & $9 \pm 3$ & 99.7 & 99.42 & 98.6 \\
$\mathrm{H}$ & $(+)$ & $60 \mathrm{~s}$ & $0 \pm 0$ & 100 & 100 & 100 \\
\hline
\end{tabular}

$2 \times 10^{8}$ E. faecalis were mixed with a final concentration of $0.83 \%$ pyoktanin blue solution (PB). RCC: The percentage of reduction in colony count.

Table II. Comparisons between groups according to E faecalis colonyforming units.

\begin{tabular}{|c|c|c|c|}
\hline Comparison & $p$-Value* & Comparison & $p$-Value* \\
\hline Group $1 \times$ group 2 & $<0.001$ & Group $2 \times$ group 7 & $<0.001$ \\
\hline Group $1 \times$ group 3 & $<0.001$ & Group $3 \times$ group 4 & $<0.001$ \\
\hline Group $1 \times$ group 4 & $<0.001$ & Group $3 \times$ group 5 & $<0.005$ \\
\hline Group $1 \times$ group 5 & $<0.001$ & Group $3 \times$ group 6 & $<0.001$ \\
\hline Group $1 \times$ group 6 & $<0.001$ & Group $3 \times$ group 7 & $<0.001$ \\
\hline Group $1 \times$ group 7 & $<0.001$ & Group $3 \times$ group 8 & $<0.001$ \\
\hline Group $1 \times$ group 8 & $<0.001$ & Group $4 \times$ group 5 & $<0.001$ \\
\hline Group $2 \times$ group 4 & $<0.001$ & Group $5 \times$ group 6 & $<0.001$ \\
\hline Group $2 \times$ group 5 & $<0.001$ & Group $6 \times$ group 7 & $<0.001$ \\
\hline Group $2 \times$ group 6 & $<0.001$ & Group $7 \times$ group 8 & $<0.001$ \\
\hline
\end{tabular}

Group 1, PB (-) Laser (-); group 2, PB (-) Laser $60 \mathrm{sec}$; group 3, PB (+) Laser (-); group 4, PB (+) Laser $10 \mathrm{sec}$; group 5, PB (+) Laser 20 sec; group 6, PB (+) Laser $40 \mathrm{sec}$; group 7, PB (+) Laser $50 \mathrm{sec}$; group 8, PB (+) Laser $60 \mathrm{sec}$ * Mann-Whitney $U$-test.

al. evaluated PDT using a diode laser and indocyanine green in a well-established root canal model and concluded that diode laser irradiation in combination with the PS had nearly the same antimicrobial effect as $2.5 \%$ sodium hypochlorite (23).

The results of the present study, which evaluated the effects of a diode laser $(808 \mathrm{~nm})$ and $\mathrm{PB}$, demonstrated that PDT with PB effectively decreased E. faecalis counts. The number of bacteria was increased following treatment with $\mathrm{PB}$ and laser irradiation at 10 and $20 \mathrm{sec}$ compared with PB without laser irradiation. We considered that the small exposure of the laser increased the activity of the bacteria and cells. Adequate laser power can increase the activity of 
bacteria and cells. However, too much power causes damage to the bacteria and cells (24-26). Biostimulatory effects of laser are governed by the Arndt-Schulz law of biology, i.e., weak stimuli excite physiological activity, whereas strong stimuli retard it (27). Previous investigators mentioned adverse effects of laser irradiation, such as temperature increase on the periapical tissue and enhancement of mammalian cell proliferation $(28,29)$. Thus, the reduction in E.faecalis cell viability was likely from laser irradiation itself, not from the heat produced by irradiation, and the addition of a PS was essential for antimicrobial effects (23). Thus, selection of the appropriate PS should be considered in PDT.

PB has been used to stain a cyst during cystic brain tumor resection $(18,19)$ and as a mouthwash (Honzou; Honsou Biological Research Institute Co., Ltd., Nagoya, Japan). In this study, incubation with $\mathrm{PB}$ for $1 \mathrm{~min}$ resulted in a significant loss of viable cells $\left(\mathrm{CC}_{50}\right.$ value $\left.=108 \mu \mathrm{g} / \mathrm{ml}\right)$. In the clinical setting, it takes less than 1 min to complete root canal irrigation with laser irradiation and $\mathrm{PB}$. Our results suggest about $10 \mu \mathrm{g} / \mathrm{ml} \mathrm{PB}$ concentration (1\%) and $1 \mathrm{~min}$ irrigation time might be optimal as $\mathrm{PB}$ was not cytotoxic to HDFa cells under these conditions.

\section{Conclusion and Summary}

Diode laser irradiation in combination with PB as the PS is efficacious for the elimination of E. faecalis without toxicity to HDFa cells. This treatment might be useful for root canal irrigants.

\section{Conflicts of Interest}

No competing financial interests exist.

\section{Acknowledgements}

This study was supported in part by a Grant-In-Aid for Scientific Research (17K11713) from the Ministry of Education, Science, and Culture of Japan.

\section{References}

1 Hargreaves KM and Berman LH: Cohen's Pathways of the Pulp. Hargreaves KM and Berman LH (eds.). St. Louis, Mosby Elsevier, pp. 632, 2011.

2 Medeiros AW, Pereira RI, Oliveira DV, Martins PD, d'Azevedo PA, Van der Sand S, Frazzon J and Frazzon AP: Molecular detection of virulence factors among food and clinical Enterococcus faecalis strains in South Brazil. Braz J Microbiol 45: 327-332, 2014.

3 Siddiqui SH, Awan KH and Javed F: Bactericidal efficacy of photodynamic therapy against Enterococcus faecalis in infected root canals: a systematic review. Photodiagnosis Photodyn Ther 10: 632-643, 2013.
4 Vera J, Siqueira JF Jr., Ricucci D, Loghin S, Fernández N, Flores $\mathrm{B}$ and Cruz AG: One- versus two-visit endodontic treatment of teeth with apical periodontitis: a histobacteriologic study. J Endod 38: 1040-1052, 2012.

5 Zang C, Du J and Peng Z: Correlation between Enterococcus faecalis and persistent intraradicular infection compared with primary intraradicular infection: a systematic review. J Endod 41: 1207-1213, 2015.

6 Du T, Wang Z, Shen Y, Ma J, Cao Y and Haapasalo M: Effect of long-term exposure to endodontic disinfecting solutions on young and old Enterococcus faecalis biofilms in dentin canals. J Endod 40: 509-514, 2014.

7 Kouchi Y, Ninomiya J, Yasuda H, Fukui K, Moriyama T and Okamoto H: Location of Streptococcus mutans in the dentinal tubules of open infected root canals. J Dent Res 59: 2038-2046, 1980.

8 Rios A, He J, Glickman GN, Spears R, Schneiderman ED and Honeyman AL: Evaluation of photodynamic therapy using a light-emitting diode lamp against Enterococcus faecalis in extracted human teeth. J Endod 37: 856-859, 2011.

9 Vatkar NA, Hegde V and Sathe S: Vitality of Enterococcus faecalis inside dentinal tubules after five root canal disinfection methods. J Conserv Dent 19: 445-449, 2017.

10 Peeters HH and Suardita K: Efficacy of smear layer removal at the root tip by using ethylenediaminetetraacetic acid and erbium, chromium: yttrium, scandium, gallium garnet laser. J Endod 37: 1585-1589, 2011.

11 Bago I, Plečko V, Gabrić Pandurić D, Schauperl Z, Baraba A and Anić I: Antimicrobial efficacy of a high-power diode laser, photoactivated disinfection, conventional and sonic activated irrigation during root canal treatment. Int Endod J 46: 339-347, 2013.

12 Stojicic S, Amorim $\mathrm{H}$, Shen $\mathrm{Y}$ and Haapasalo $\mathrm{M}$ : Ex vivo killing of Enterococcus faecalis and mixed plaque bacteria in planktonic and biofilm culture by modified photoactivated disinfection. Int Endod J 46: 649-659, 2013.

13 Hamblin MR and Hasan T: Photodynamic therapy: a new antimicrobial approach to infectious disease? Photochem Photobiol Sci 3: 436-450, 2004.

14 Deminova TN and Hamblin MR: Photodynamic therapy targeted to pathogens. Int J Immunopathol Pharmacol 17: 245254, 2004.

15 Afkhami H, Akbari S and Chiniforush N: Enterococcus faecalis elimination in root canals using silver nanoparticles, photodynamic therapy, diode laser, or laser-activated nanoparticles: An in vitro study. J Endodont 43: 279-282, 2017.

16 Boehm TK and Ciancio SG: Diode laser activated indocyanine green selectively kills bacteria. J Int Acad Periodontol 13: 5863, 2011.

17 Chiniforush N, Pourhajibagher M, Shahabi S and Bahador A: Clinical approach of high technology techniques for control and elimination of endodontic microbiota. J Lasers Med Sci 6: 139$150,2015$.

18 Hayashi N, Sasaki T, Tomura N, Okada H and Kuwata T. Removal of a malignant cystic brain tumor utilizing pyoktanin blue and fibrin glue: Technical note. Surg Neurol Int 8: 24, 2017.

19 Tomita Y, Sasaki T, Tanabe T, Idei M, Muraoka K, Terada K, Meguro T, Hirotsune N and Nishino S: Pyoktanin blue injection for resection of cystic brain tumor: a case report. No Shinkei Geka 41: 687-691, 2013. 
20 Sakagami H, Uesawa Y, Ishihara M, Kagaya H, Kanamoto T, Terakubo S, Nakashima H, Takao K and Sugita Y: Quantitative structure-cytotoxicity relationship of oleoylamides. Anticancer Res 35: 5341-5355, 2015.

21 Generali L, Cavani F, Serena V, Pettenati C, Righi E and Bertoldi C: Effect of different irrigation systems on sealer penetration into dentinal tubules. J Endod 43: 652-656, 2017.

22 Costa Lima GA, Aguiar CM, Câmara AC, Alves LC, Brayner dos Santos FA and Nascimento AE: Comparison of smear layer removal using the Nd:YAG laser, ultrasound, ProTaper Universal system, and CanalBrush methods: an in vitro study. J Endod 41: 400-403, 2017.

23 Nagayoshi M, Nishihara T, Nakashima K, Iwaki S, Chen KK, Terashita $\mathrm{M}$ and Kitamura C: Bactericidal effects of diode laser irradiation on Enterococcus faecalis using periapical lesion defect model. ISRN Dentistry 2011: 870364, 2011.

24 Migliario M, Pittarella P, Fanuli M, Rizzi M and Renò F: Laserinduced osteoblast proliferation is mediated by ROS production Lasers Med Sci 29: 1463-1467, 2014.

25 Ogita M, Tsuchida S, Aoki A, Satoh M, Kado S, Sawabe M, Nanbara H, Kobayashi H, Takeuchi Y, Mizutani K, Sasaki Y, Nomura $\mathrm{F}$ and Izumi $\mathrm{Y}$ : Increased cell proliferation and differential protein expression induced by low-level Er:YAG laser irradiation in human gingival fibroblasts: proteomic analysis. Lasers Med Sci 30: 1855-1866, 2015.
26 Kong S, Aoki A, Iwasaki K, Mizutani K, Katagiri S, Suda T, Ichinose S, Ogita M, Pavlic V and Izumi Y: Biological effects of Er:YAG laser irradiation on the proliferation of primary human gingival fibroblasts. J Biophotonics 11, 2018. doi: 10.1002/jbio.201700157. [Epub ahead of print].

27 Tuner $\mathrm{J}$ and Hode L: The new laser therapy handbook. Nobel A (ed.). Grängesberg, Prima Books AB, pp. 514, 2010.

28 Scoop U, Kluger W, Moritz A, Nedjelik N, Georgopoulos A and Sperr W: Bactericidal effect of different laser systems in the deep layers of dentin. Lasers in Surg Med 35: 111-116, 2004.

29 Hirata S, Kitamura C, Fukushima H, Abiko Y, Terashita M and Jimi E: Low level laser enhances BMP-induced osteoblast differentiation by stimulating the BMP/Smad signaling pathway. J Cellular Biochem 111: 1445-1452, 2010.

Received February 28, 2018

Revised April 11, 2018

Accepted April 13, 2018 